\title{
KEDUDUKAN HUKUM OBJEK JAMINAN SERTIPIKAT HAK MILIK YANG DIAMBIL ALIH OLEH KREDITOR (AYDA) SEBAGAI BADAN HUKUM DENGAN AKTA DE COMMAND
}

\author{
Riska Fibrianti \\ Alumni Program Studi Magister Kenotariatan \\ Pascasarjana Universitas Islam Bandung \\ Email : riska.fibrianti@yahoo.com
}

\begin{abstract}
Abstrak: Pemberian kredit biasanya selalu disertai dengan pemberian adanya suatu jaminan. Setiap hal yang berkaitan dengan pembuatan perjanjian tambahan (accesoir) berkaitan dengan jaminan, maka para pihak dilarang membuat janji bagi kreditur untuk dapat langsung memiliki objek jaminan apabila debitur wanprestasi. Pada praktiknya, seringkali dijumpai pemberian kredit dengan jaminan yang memberikan hak kreditur untuk dapat langsung menjadi pemilik benda yang dijadikan jaminan apabila debitur dalam keadaan wanpretasi. Menjadi persoalan ketika pelaksanaan Aset Yang Diambil Alih (AYDA) oleh kreditor atas debitor mengalami kredit macet, serta kedudukan hukum objek jaminan diambil alih (AYDA) oleh kreditor sebagai badan hukum dengan Akta De Command. Tujuan penelitian ini adalah untuk mengkaji dan menganalisis pelaksanaan AYDA oleh kreditor atas debitor yang mengalami kredit macet, serta kedudukan hukum objek jaminan sertipikat hak milik merupakan AYDA oleh kreditor sebagai badan hukum dengan Akta De Command. Penelitian ini menggunakan metode pendekatan secara yuridis normatif. Hasil penelitian bahwa Upaya penyelamatan kredit macet adalah dengan melakukan pengambilalihan asset debitur (AYDA) dan terkait dengan pemilikan agunan oleh bank berdasarkan Pasal 12 UU No.4 Tahun 1996 yang pada pokoknya mengatur bahwa pemberian kewenangan kapada pemegang hak tanggungan terjadi apabila debitur cidera janji. Sertifikat Hak Milik harus dialihkan atas nama perorangan tidak boleh atas nama PT.
\end{abstract}

Kata Kunci: Kredit Macet, AYDA, Agunan, Akta De Command.

\begin{abstract}
The provision of credit is usually accompanied by the provision of guarantee. Anything related to the making of additional agreements (accesoir) related to guarantees, the parties are prohibited from making promises for the creditor to immediately have the object of guarantee if the debtor defaults. In practice, it is frequently found that the provision of credit with guarantees gives the creditor the right to become the owner of the object that is used as collateral if the debtor is in a state of default. It becomes a problem when the implementation of Foreclosed Assets (AYDA) by creditors on debtors experiencing bad credit, and the legal position of the object of collateral is taken over (AYDA) by creditors as a legal entity with a De Command Deed. The purpose of this study was to study and analyze the implementation of AYDA by creditors on debtors who experience bad credit, as well as the legal position of the object of the certificate of ownership is AYDA by creditors as a legal entity with De Command Deed. This study used a normative juridical approach. The results showed that the efforts to save bad credit are by taking over the debtor's assets (AYDA) and related to the collateral ownership by the bank based on Article 12 of Law Number 4 Year 1996, which basically regulates that the granting of authority to the mortgage holder occurs when the debtor is in default. Freehold Title must be transferred on behalf of an individual, not on behalf of PT.
\end{abstract}

Key Words: Bad Credit, AYDA, Collateral, De Command Deed. 


\section{A. PENDAHULUAN}

Bank merupakan salah satu finacial intermediary. Sebagai Lembaga perantara keuangan, bank memiliki fungsi menghimpun dana dari pihak yang memiliki kelebihan dana (surplus of funds) dan menyalurkannya kepada pihak yang memerlukan dana (lack of funds). (Neni Sri Imaniyati, 2011). Dalam hal penghimpunan dana masyarakat, kepercayaan masyarakat untuk menyimpan dananya pada bank merupakan modal utama bank. (Neni Sri Imaniyati, 2008). Pemberian kredit merupakan kegiatan utama bank yang mengandung resiko yang dapat berpengaruh pada kesehatan dan kelangsungan usaha bank, sehingga dalam pelaksanaannya bank harus berpegang pada asas-asas perkreditan yang sehat guna melindungi dan memelihara kepentingan dan kepercayaan masyarakat.

Pemberian kredit lahir berdasarkan persetujuan atau kesepakatan pinjam meminjam uang antara bank sebagai kreditor dan nasabah peminjam dana sebagai debitor dalam jangka waktu tertentu yang telah disepakati bersama dan akan melunasi hutangnya dengan sejumlah bunga, imbalan atau pembagian hasil keuntungan.

Perjanjian kredit menurut hukum Perdata termasuk dalam perjanjian pinjam meminjam yang diatur dalam pasal 1754-1769 KUHPerdata. Menurut pasal 1754 KUHPerdata disebutkan bahwa :
"Pinjam meminjam adalah suatu perjanjian dengan mana pihak yang satu memberikan kepada pihak yang lain suatu jumlah barang tertentu dan habis pemakaian dengan syarat bahwa yang belakangan ini akan mengembalikan sejumlah yang sama dari macam keadaan yang sama pula."

Pada setiap pemberian kredit bank dan nasabah lazimnya memperjanjikan berbagai hal seperti jangka waktu pemberian fasilitas, kewajiban pembayaran kembali disertai dengan jadwal atau rencana pembayaran angsuran pokok dan bunga serta kewajiban lain yang harus dipenuhi. Apabila dalam hal perkembangannya, debitor mulai memperlihatkan tanda-tanda mulai menunggak membayar angsuran pokok dan bunga, (Indrawati, Soewarso, 2002 : 109) Kredit yang bersangkutan mulai mengahadapi masalah. Dengan adanya kredit bermasalah maka bank tengah menghadapi resiko usaha, jenis resiko kredit (default risk) yaitu resiko akibat ketidakmampuan nasabah/ debitor mengembalikan pinjaman yang diterimanya dari bank beserta bunganya sesuai dengan jangka waktu yang telah ditentukan. (Muhammad Abdulkadir, Murniati Rilda, 2000 : 97).

Resiko ialah kewajiban memikul kerugian yang disebabkan karena suatu kejadian di luar kesalahan salah satu pihak. (Subekti, 2002: 59). Persoalan tentang risiko itu berpokok- 
pangkal pada terjadinya suatu peristiwa diluar kesalahan salah satu pihak. Peristiwa semacam itu dalam hukum perjanjian dengan suatu istilah hukum dinamakan "keadaan memaksa" ("overmacht", "force majeur"), dengan demikian persoalan tentang risiko itu merupakan buntut dari persoalan tentang keadaan memaksa, suatu kejadian yang tak disengaja dan tak dapat diduga. (Subekti, 1995: 25). Berdasarkan uraian tentang pengertian resiko di atas tadi, persoalan resiko itu berpangkal pada terjadinya suatu peristiwa di luar kesalahan salah satu pihak yang mengadakan perjanjian, dengan kata lain berpokok pangkal pada kejadian yang dalam hukum perjanjian dinamakan keadaan memaksa. Persoalan risiko adalah buntut dari suatu keadaan memaksa, sebagaimana ganti rugi adalah buntut dari wanprestasi.

Dalam pemberian kredit, bank menghendaki adanya suatu jaminan atau agunan yang dapat digunakan sebagai pengganti pelunasan hutang bilamana dikemudian hai debitor cidera janji atau wanprestasi. Jaminan kredit merupakan pelunasan yang diberikan oleh debitor dengan cara mengeksekusi obyek jaminan kredit. Jaminan yang umumnya digunakan oleh Bank adalah jaminan kebendaan yang salah satunya adalah tanah berikut segala sesuatu yang ada diatasnya, baik yang ada sekarang maupun yang akan ada di kemudian hari yang dijadikan jaminan. Pihak Bank harus melakukan tindakan untuk menguasai jaminan tersebut secara efektif, baik melalui pengikatan dan/atau pemblokiran rekening/dana dan/atau penguasan fisik jaminan. Undang-undang telah menentukan secara tegas bentuk pengikatan jaminan yang dilakukan atas benda tidak bergerak, untuk jaminan berupa tanah yang dapat diterima sebagai jaminan adalah tanah yang berstatus dan telah mempunyai Sertifikat Hak Milik, Hak Guna Bangunan, Hak Guna Usaha atau Hak Pakai Atas Tanah Negara (yang karena ketentuan perundang-undangan harus didaftar dan karena sifatnya dapat di pindah tangankan) dimana untuk tanah-tanah jenis ini pengikatannya dilakukan dengan Hak Tanggungan. Undang-Undang Nomor 4 Tahun 1996 tentang Hak Tanggungan atas tanah serta benda-benda yang berkaitan dengan tanah menjelaskan mengenai pengertian Hak Tanggungan yaitu Hak Tanggungan adalah hak jaminan atas tanah untuk pelunasan hutang tertentu, yang memberikan kedudukan diutamakan kepada kreditor tertentu terhadap kreditor-kreditor lain.

Hak Tanggungan itu merupakan hak jaminan kebendaan terhadap hak atas tanah untuk pelunasan hutang tertentu, dengan memberikan kedudukan yang diutamakan kepada kreditor tertentu pemegang hak tanggungan terhadap kreditor lain. Jaminan yang diberikan kepada kreditor sebagai pemegang Hak Tanggungan adalah hak yang diutamakan atau mendahulu dari kreditor- 
Riska Fibrianti, Kedudukan Hukum Objek Jaminan Sertipikat Hak Milik Yang Diambil Alih Oleh Kreditor (Ayda) Sebagai..

kreditor lainnya bagi kreditor (Pemegang Hak Tanggungan). (Rachmadi Usman, 2008 : 332).

Salah satu cara yang ditempuh pihak bank dalam penanganan eksekusi hak jaminan atas kredit macet yakni melalui penjualan dibawah tangan. Ketentuan undang-undang membuka kemungkinan bagi kreditor untuk melakukan penjualan secara dibawah tangan yang seharusnya melalui pelelangan jika dengan cara yang demikian dapat diperoleh harga tertinggi yang menguntungkan semua pihak.

Selain penjualan dibawah tangan yang dianggap dapat mengatasi kesulitan yang timbul dalam penjualan secara lelang, khusus bagi bank ketentuan undang-undang menetapkan kemungkinan untuk membeli sendiri barang jaminan meskipun hal tersebut besifat sementara atau pengambil alihan agunan oleh bank, dewasa ini dikenal dengan sebutan agunan yang diambil Alih (AYDA). Praktek pelaksanaan AYDA dilakukan karena terdapatnya berbagai hambatan atau kendala dalam pelaksanaan eksekusi Hak Tanggungan yang merugikan pihak bank sebagai kreditor serta salah satu upaya jangka pendek bank untuk mengatasi tingginya jumlah kredit macet yang berpengaruh besar terhadap kelangsungan usaha bank itu sendiri.

Merujuk pada ketentuan Bab I ketentuan Umum, khususnya Pasal 1 angka 24 Peraturan Bank Indonesia No. 9/9/PBI/2007 tentang perubahan Atas peraturan Bank Indonesia No. 8/21/PBI/2006 tentang penilaian Kualitas
Aktiva Bank Umum yang melaksanakan Kegiatan usaha Berdasarkan Prinsip Syariah yang dimaksud dengan AYDA adalah :

“... aktiva yang diperoleh Bank, baik melalui pelelangan maupun diluar pelelangan berdasarkan penyerahan secara sukarela oleh pemilik agunan atau berdasarkan kuasa umtuk menjual di luar lelang dari pemilik agunan dalam hal nasabah tidak memenuhi kewajibannya kepada Bank.”

Hal yang dimaksud dengan AYDA adalah suatu aktiva yang diperoleh bank melalui pelelangan maupun diluar lelang dari pemilik agunan, karena pemilik agunan/debitor lalai dalam memenuhi kewajibannya.

Pada awalnya penyelesaian kredit dengan cara jual beli barang agunan diluar lelang adalah tidak diperkenankan oleh undangundang. Hal ini dapat dilihat dari ketentuan pasal 6k Undang-Undang No. 7 Tahun 1992 yang berbunyi :

“...Usaha Bank Umum meliputi : membeli melalui pelelangan agunan baik semua maupun sebagian dalam hal debitor tidak memenuhi kewajibannya kepada bank, dengan ketentuan agunan yang dibeli tersebut wajib dicairkan secepatnya."

Dalam ketentuan Undang-Undang tersebut pembelian harus melalui pelelangan umum, sehingga pembelian diluar lelang tidak diperbolehkan. Namun berdasarkan Pasal 12 A 
Riska Fibrianti, Kedudukan Hukum Objek Jaminan Sertipikat Hak Milik Yang Diambil Alih Oleh Kreditor (Ayda) Sebagai..

Undang-Undang Nomor 10 Tahun 1998 tentang Perubahan Atas Undang-Undang Nomor 7 tahun 1992 tentang perbankan yang menghapus ketentuan Pasal 6 k Undang-Undang Nomor 7 Tahun 1992 tentang perbankan menyebutkan sebagai berikut :

“ Bank Umum dapat membeli sebagian atau seluruh agunan, baik melalui pelelangan maupun di luar pelelangan berdasarkan penyerahan secara sukarela oleh pemilik agunan atau berdasarkan kuasa untuk menjual di luar lelang dari pemilik agunan dalam hal nasabah debitor tidak memenuhi kewajibannya kepada bank, dengan ketentuan agunan yang dibeli tersebut wajib dicairkan secepatnya."

Dengan adanya ketentuan Pasal 12 A Undang-Undang Nomor 10 tahun 1998 tentang Perubahan Atas Undang-Undang Nomor 7 Tahun 1992 tentang Pebankan tersebut diatas, memberikan keleluasaan bagi bank dan debitor dalam mengusahakan penyelesaian kredit macet diantara mereka melalui pembelian diluar pelelangan berdasarkan penyerahan secara sukarela oleh pemilik agunan atau berdasarkan kuasa untuk menjual diluar lelang dari pemilik agunan. Agunan yang dibeli oleh bank secepatcepatnya harus dijual kembali atau dicairkan selambat-lambatnya dalam jangka waktu satu tahun, agar hasil penjualan agunan dapat segera dimanfaatkan oleh bank.
Peraturan Bank Indonesia Nomor 14/15/PBI/2012 tentang Penilaian Kualitas Aset Bank Umum memuat ketentuan mengenai pengambilalihan aset debitor dalam ketentuan umum Pasal 1 ayat (15) yaitu mengenai Agunan Yang Diambil Alih (AYDA). Hal tersebut bertentangan dengan Pasal 12 UUHT yang menyebutkan bahwa janji yang memberikan kewenangan kepada pemegang Hak Tanggungan untuk memiliki obyek Hak Tanggungan apabila debitor cidera janji, maka batal demi hukum.

Berdasarkan pada uraian diatas penulis merasa perlu mengkaji lebih dalam mengenai pelaksanaan Aset Yang Diambil Alih (AYDA) oleh kreditor atas debitor yang mengalami kredit macet, dan bagaimana Kedudukan Hukum Objek Jaminan (Sertipikat Hak Milik) Asset Yang Diambil Alih (AYDA) Oleh Kreditor Sebagai Badan Hukum Dengan Akta De Command.

Berdasarkan latar belakang diatas, maka dirumuskan masalah sebagai berikut:

1. Bagaimana Pelaksanaan Aset Yang Diambil Alih (AYDA) Oleh Kreditor Atas Debitor yang Mengalami Kredit Macet?

2. Bagaimana Kedudukan Hukum Objek Jaminan Sertipikat Hak Milik Yang Diambil Alih (AYDA) Oleh Kreditor Sebagai Badan Hukum Dengan Akta De Command?

3. 


\section{METODE PENELITIAN}

Penelitian ini menggunakan metode pendekatan secara yuridis normatif, yaitu dengan cara meneliti dan mengkaji data sekunder berupa hukum positif yang terkait dengan pokok permasalahan yang diteliti. Obyek penelitian normaif antara lain asas-asas hukum, sistematik hukum, taraf sinkronisasi vertical dan horisontal. (Sudikno Mertokusumo, 2010: 37). Penelitian ini bersifat deskriptif analitis karena penelitian ini menggambarkan situasi atau peristiwa yang sedang diteliti dan menganalisisnya berdasarkan fakta-fakta berupa data primer yang diperoleh dari wawancara terhadap narasumber yang bersangkutan, sedangkan data sekunder diperoleh dari bahan hukum primer, bahan hukum sekunder maupun bahan hukum tersier.

\section{B. PEMBAHASAN}

1. Pelaksanaan Aset Yang Diambil Alih (AYDA) Oleh Kreditor Atas Debitor yang Mengalami Kredit Macet

Kredit merupakan risk asset bagi bank karena aset bank itu dikuasai pihak luar bank yaitu para debitor. Namun kredit yang diberikan kepada para debitor selalu ada resiko berupa kredit yang tidak dapat kembali tepat pada waktunya yang dinamakan kredit bermasalah atau Non Performing Loan (NPL). Kredit bermasalah selalu ada dalam kegiatan perkreditan bank karena bank tidak mungkin menghindarkan adanya kredit yang bermasalah, namun bank sedapat mungkin berusaha menekan besarnya jumlah kredit bermasalah. Untuk menyelesaikan kredit bermasalah Non Performing Loan (NPL) ada 2 (dua) strategi yang dapat ditempuh yaitu : (Suharno, 2003: 265).

1. Penyelamatan Kredit

Penyelamatan adalah suatu langkah penyelesaian kredit bermasalah melalui perundingan kembali antara kreditor dan debitor dengan memperingan syaratsyarat pengembalian kredit sehingga dengan memperingan syarat-syarat pengembalian tersebut diharapkan debitor memiliki kemampuan kembali untuk menyelesaikan kredit. Pada tahap penyelamatan kredit ini belum memanfaatkan Lembaga hukum karena debitor masih kooperatif dan ari prospek usaha masih feasible. Langkah penyelesaian melalui restrukturisasi kredit ini diperlukan syarat paling utama yaitu adanya kemauan dan itikad baik dan kooperatif dari debitor serta bersedia menikuti syarat-syarat yang ditentukan bank karena dalam penyelesaian kredit melalui restruktuisasi lebih banyak negoisasi dan solusi yang ditawarkan bank untuk menentukan syarat dan ketentuan restrukturisasi kredit.

2. Penyelesaian kredit

Penyelesaian kredit adalah langkah penyelesaian kredit bermasalah melalui 
Lembaga hukum seperti pengadilan atau direktorat Jenderal Piutang dan Lelang Negara atau badan lainnya dikarenakan langkah penyelamatan sudah tidak dimungkinkan kembali. tujuan penyelesaian kredit melalui Lembaga hukum ini adalah untuk menjual atau mengeksekusi benda jaminan.

Faktor-faktor penyebab penyelesaian kredit macet melalui AYDA antara lain: 1) Pengambilalihan asset debitr (AYDA) berupa tanah dan bangunan harus dilakukan apabila kredit sudah masuk ke dalam kategori kredit macet; 2) Debitor tidak mempunyai kemampuan membayar; 3) Hilangnya pekerjanan debitor; 4) Debitor selalu ingkar dan tidak kooperatif dalam pembayaran; 5) Tidak ada iktikad baik dalam pembayaran;

Debitor hanya sebagai atas nama, dan pemakai kredit tidak diketahui keberadaanya. Proses pengalihan terhadap barang-barang agunan dapat dilakukan melalui 2 (dua) cara, yakni: (www.hukumonline.com, Diakses pada tanggal 23Februari 2020).

1) Melalui mekanisme lelang; 2) Melalui mekanisme penjualan dibawah tangan dengan persetujuan pemilik agunan.

Lelang (penjualan umum) adalah setiap pelunasan barang dimuka umum dengan cara penawaran harga secara lisan dan/tulis melalui usaha mengumpulkan para peminat atau peserta lelang. Lelang sebagai sarana penjualan barang yang bersifat khusus dan transparan. Fungsi publik dari lelang tercermin dari 3 (tiga) hal, yaitu: 1) Mengamankan asset yang dimiliki atau dikuasai negara untuk meningkatkan efisiensi dan tertib administrasi dari pengelolaan asset tersebut; 2) Pelayanan penjualan barang dalam rangka mewujudkan law eforcement yang mencerminkan keadilan, keamanan, dan kepastian hokum; 3) Mengumpulkan penerimaan negara dalam bentuk bea lelang dan uang miskin. Penjualan barang secara lelang sebagai suatu sistem penjualan yang memenuhi rasa keadilan, keamanan, kecepatan dengan harga wajar serta menjamin adanya kepastian hukum. Adil, karena penjualannya dilakukan secara terbuka untuk umum, sehingga langsung dapat dikontrol masyarakat. Aman, karena lelang dilaksanakan oleh Pejabat Lelang sebagai pejabat umum yang ditunjuk untuk itu dan diangkat oleh Pemerintah. Cepat, karena adanya pengumuman lelang terlebuh dahulu lewat surat kabar dan pembayaran lelang dilakukan secara tunai. Harga wajar, tercermin adanya sistem penawaran yang melalui mekanisme lelang, atau melalui mekanisme penjualan dibawah tangan dengan persetujuan pemilik agunan.

Jaminan kredit macet, lazimnya akan dijual untuk menutupi kewajiban debitor. Penjualan pada umumnya dilakukan melalui cara lelang, namun ketentuan undang-undang khususnya Undang-Undang Nomor 4 tahub 1996 tentang Hak Tanggungan pada pasal 20 ayat (2) memngkinkan dilakukannya penjualan secara dibawah tangan jika dengan cara yang 
Riska Fibrianti, Kedudukan Hukum Objek Jaminan Sertipikat Hak Milik Yang Diambil Alih Oleh Kreditor (Ayda) Sebagai..

demikian dapat diperoleh harga tertinggi yang menguntungkan semua pihak.

Selain dengan penjualan dibawah tangan, ketentuan undang-undang menetapkan kemungkinan untuk membeli sendiri barang jaminan melalui pelaksaan pengambilalihan aset debitor. Salah satu upaya penyelesaian kredit macet pada bank yang diatur melalui Surat keputusan Direksi Bank Indonesia No. 31/150/KEP/DIR tanggal 12 November 1998 tentang Restrukturisasi kredit yang telah diubah dengan peraturan Bank Indonesia No. 2/15/PBI/2000 adalah dengan dilakukannya pengambilalihan agunan/asset debitor atau dewasa ini dikenal dengan sebutan AYDA (Aset Yang Diambil Alih). Bank dimungkinkan untuk membeli sendiri agunan/aset meskipun hal tersebut bersifat sementara. Bank diwajibkan untuk secepatnya melakukan pencairan kembali atas agunan yang dibeli baik melalui lelang atau diluar lelang melalui penyerahan secara sukarela oleh debitor, agar dana hasil pencairan dari penjualan agunan tersebut dapat segera dimanfaatkan oleh bank. Ketentuan seperti ini adalah salah satu upaya untuk mencegah kerugian yang lebih besar bagi bank yang memilik kredit macet. (Bachtiar, Sibarani, $2001: 48$ )

Merujuk pada ketentuan Bab I ketentuan Umum, khususnya Pasal 1 angka 24 Peraturan Bank Indonesia No. 9/9/PBI/2007 tentang perubahan Atas peraturan Bank Indonesia No. 8/21/PBI/2006 tentang penilaian Kualitas
Aktiva Bank Umum yang melaksanakan Kegiatan usaha Berdasarkan Prinsip Syariah yang dimaksud dengan AYDA adalah aktiva yang diperoleh Bank, baik melalui pelelangan maupun diluar pelelangan berdasarkan penyerahan secara sukarela oleh pemilik agunan atau berdasarkan kuasa umtuk menjual di luar lelang dari pemilik agunan dalam hal nasabah tidak memenuhi kewajibannya kepada Bank. Sehingga yang dimaksud dengan AYDA adalah suatu aktiva yang diperoleh bank melalui pelelangan maupun diluar lelang dari pemilik agunan, karena pemilik agunan/debitor lalai dalam memenuhi kewajibannya.

Pelaksanaan AYDA melalui pelelangan dapat kita temui dalam ketentuan Pasal 6 Undang-Undang Nomor 4 tahun 1996 tentang Hak Tanggungan yang menyatakan bahwa apabila debitor cidera janji, maka pemegang Hak Tanggngan pertama dalam hal ini bank mempunyai hak untuk menjual objek Hak Tanggungan atas kekuasaan sendiri melelui pelelangan umum. Selain itu bank sebagai pemegang Hak Tanggungan juga dimungkinkan untuk menjadi pembeli objek hak tanggungan dalam hal dilakukannya lelang atas agunan apabila debitor cidera janji.

Tujuan dilakukannya penyelesaian kredit macet melalui pengambilalihan aset debitor (AYDA) adalah :

1. Untuk menekan jumlah kredit macet (Non Performing Loan) pada suatu bank 
2. Untuk mempercepat dan mempermudah proses penyelesaian kredit, karena hal ini dilakukan berdasarkan kesepakatan antara bank dengan debitor

3. Untuk mengantisipasi segala akibat yang timbul dalam waktu dekat akibat jumlah kredit macet yang semakin meningkat.

Proses pelaksanaan penyelesaian kredit macet melalui pengambilalihan aset debitor/Asset settlement (AYDA) dilakukan dengan prosedur sebagai berikut : (www.ontar.ui.ac.id, Diakses pada tanggal 24 Februari 2020).

1. Penyerahan sukarela oleh debitor dilakukan dengan membuat perjanjian penyerahan asset/penyelesaian kredit, Akta Jual Belia tau perjanjian pengikatan jual beli dan kuasa jual.

2. Lelang hak tanggungan via KPKNL/Kantor Lelang Negara melalui Risalah Lelang

3. Pengambilalihan melalui proses hukum/litigasi/lelang eksekusi via Pengadilan Negeri melalui Risalah Lelang.

Bank bertindak selaku pembeli barang jaminannya sendiri dalam lelang eksekusi atau biasa dikenal dengan istilah Aset Yang Diambil Alih (AYDA) berpotensi meningkatkan produktifitas lelang dan mempercepat penyelesaian kewajiban debitor. Dan Penggunaan Akta De Command Dalam Rangka Bank Umum Swasta Sebagai Pembeli Obyek
Lelang. (www.djkn.kemenkeu.go.id, Diakses pada tanggal 23 Februari).

Menurut Dedy Christanto, Pelelang Ahli Madya pada Kantor Pelayanan Kekayaan Negara dan Lelang (KPKNL) Jakarta V saat memberikan materi tentang Lelang Eksekusi Hak Tanggungan Dan Penggunaan Akta De Command Dalam Rangka Bank Umum Swasta Sebagai Pembeli Obyek Lelang di Sinarmas Learning Center Bank Sinarmas, menjelaskan bahwa seringkali pembeli lelang enggan membeli barang yang dilelang karena barang tersebut dijual apa adanya beserta segala kekurangannya, misalnya dalam keadaan masih dikuasai debitor, "Kalau asetnya di beli oleh bank, kemudian bank melakukan upaya pengosongan, dan aset itu dijual lagi dalam keadaan kosong, pembeli akan lebih tertarik," ujarnya. (Ibid).

Melelang agunan debitor yang kreditnya macet menjadi pilihan perbankan untuk menutupi utang debitor kepada Bank, hal ini menjadi salah satu cara untuk menekan angka Non Performing Loan (NPL) atau kredit macet. Pelelangan yang dilakukan oleh perbankan akan melibatkan Kantor Pelayanan Kekayaan Negara dan Lelang (KPKNL). Sebelum proses lelang terjadi, perbankan akan berkoordinasi dengan KPKNL untuk selanjutnya diumumkan akan adanya pelelangan itu di media massa.

Bank mengajukan permohonan lelang secara tertulis ke Kantor Pelayanan Kekayaan Negara dan Lelang (KPKNL), setelah dilakukan 
pelelangan terhadap agunan dan tidak terjual, maka barulah Bank dapat mengambil langkah penyelesaian kredit macet melalui pengambilalihan aset debitor. Bank akan memusyawarahkan hal ini dengan debitor, apabila disepakati maka pihak bank akan melaksanakan pengambil alihan agunan, kesepakatan dapat dituangkan dalam perjanjian tertulis atau dalam berita acara penyelesaian kredit yang ditandatangani oleh debitor diatas materai, hal ini dibutuhkan sebagai bentuk ketersediaan dan kesukarelaan debitor dalam penyerahan agunannya, walaupun pada prakteknya pengambil alihan dilakukan dengan mekanisme penjualan di bawah tangan antara debitor/ pemilik agunan dengan Bank sebagai pembeli.

Asas Lex Superior Derogat Legi Inferiori menyatakan bahwa peraturan yang lebih rendah tidak boleh bertentangan dengan peraturan yang lebih tinggi. Peraturan yang lebih tinggi akan mengesampingkan peraturan yang lebih rendah. Ketentuan Pasal 12 UndangUndang Hak Tanggungan (UUHT) bertentangan dengan ketentuan AYDA dalam Pasal 1 ayat (15) Peraturan Bank Indonesia Nomor 14/15/PBI/2012 tentang Penilaian Kualitas Aset Bank Umum, maka seharusnya hal tersebut bertentangan dengan Asas Lex Superior Derogat Legi Inferiori.

Bank dalam prakteknya dapat melaksanakan AYDA sebagai langkah penyelesaian kredit macet, untuk itu dalam DOI: https://doi.org/10.29313/aktualita.v0i0.5903 kasus AYDA asas tersebut tidak sepenuhnya bertentangan, karena sebelum melakukan AYDA, Bank terlebih dahulu melakukan eksekusi obyek jaminan Hak Tanggungan melalui pelelangan umum sesuai ketentuan Pasal 6 UUHT, dalam hal obyek lelang tidak laku terjual, maka barulah Bank mengambil langkah penyelesaian kredit macet melalui AYDA atas dasar kesepakatan. Bank mengambil langkah AYDA dengan tujuan untuk likuiditas Bank, terkait pelunasan hutang debitor kepada Bank.

Bank yang melakukan AYDA terhadap debitor macet kemudian dapat melakukan hapus buku dan hapus tagih. Hapus buku merupakan tindakan bank secara administratif untuk menghapus bukukan atas kredit macet dari neraca kewajiban debitor tanpa menghapus hak tagih dari bank kepada debitor, sedangkan hapus tagih adalah tindakan dari bank untuk menghapus semua kewajiban dari debitor macet yag sama sekali tidak dapat diselesaikan. Bank dalam melakukan hapus buku dan hapus tagih harus tunduk pada ketentuan Bank Indonesia. Pelaksanaan hapus tagih seringkali mengakibatkan bank mengalami kerugian, karena bank seolah-olah harus membiarkan debitor yang wanprestasi tersebut tidak membayar kewajibannya, oleh sebab itu bank sangat jarang melakukan hal ini dan pelaksanaan hapus tagih adalah upaya yang terakhir bagi bank dalam menghadapi kredit bermasalah. 
2. Kedudukan Hukum Objek Jaminan Sertipikat Hak Milik Yang Diambil Alih (AYDA) Oleh Kreditor Sebagai Badan Hukum Dengan Akta De Command

Dalam hal menunjang kegiatan pemenuhan kebutuhan, manusia membutuhkan suatu modal yang seringkali diperoleh dari lembaga keuangan yang memberikan fasilitas kredit bagi masyarakat melalui sistem pembayaran angsuran. Dalam pemberian kredit, antara pihak debitor dan kreditor diikat dengan suatu perjanjian yang disebut perjanjian kredit. (Alifah Rana, 2019 : 1165) Setiap perjanjian kredit yang menyebabkan seseorang menjadi terikat dengan pihak lawan dalam KUHPerdata tepatnya pada Pasal 1131, segala benda miliknya pun ikut terikat sebagai jaminan atas perikatan tersebut. Jaminan yang diberikan oleh Pasal 1131 KUHPerdata ini bersifat umum, artinya bahwa jaminan ini diberikan untuk semua pihak yang berkedudukan sebagai kreditor. Namun, kedudukan kreditor dengan jaminan umum ini hanya sebagai kreditor konkuren, dimana tidak ada yang diutamakan dalam pelunasan utang. Sehingga terdapat alternatif lain yang sering digunakan dalam pemberian kredit, yaitu jaminan kebendaan yang melahirkan hak kebendaan dan menyebabkan kreditor pemegang jaminan kebendaan ini menjadi kreditor preferen.

Pada asasnya tidak ada kredit yang tidak mengandung jaminan. (J Satrio, 1993 : 10)
Pemberian jaminan tersebut berfungsi sebagai bentuk kepastian akan pelunasan utang oleh debitor. Pembebanan benda sebagai objek jaminan menggunakan lembaga jaminan yang disesuaikan dengan jenis benda yang dijadikan objek jaminan. Dalam KUHPerdata dikenal beberapa jenis benda yang menyebabkan perbedaan lembaga jaminan yang digunakan disesuaikan dengan jenis-jenis benda. KUHPerdata Dalam semua peraturan perundang-undangan mengenai lembaga jaminan terdapat ketentuan yang merupakan bentuk perlindungan hukum terhadap kepentingan debitor atau pemilik jaminan. Ketentuan tersebut menyatakan mengenai adanya larangan pencantuman klausul pemilikan objek jaminan oleh kreditor secara otomatis.

Dalam lembaga jaminan gadai, benda yang dijadikan objek jaminan harus berada dalam kekuasaan pihak kreditor atau pihak ketiga. Dalam Pasal 1152 ayat (2) KUHPerdata disebutkan bahwa tidak sah hak gadai atas barang yang tetap berada pada kekuasaan si berutang atau si pemberi gadai (pola Inbezitstelling). Penyerahan benda gadai pada kreditor atau pihak ketiga hanya sebagai syarat untuk lahirnya hak kebendaan yaitu hak gadai. Sehingga apabila debitor wanprestasi, kreditor tidak dapat secara langsung memiliki benda yang dijadikan objek gadai karena penguasaan atas benda jaminan tersebut bukan berasal dari penyerahan dalam arti levering yang 
sebenarnya. Penyerahan objek gadai kepada kreditor atau pihak ketiga hanya sebagai jaminan atas pelunasan utang.

Dalam lembaga jaminan hipotek, larangan kreditor untuk memiliki benda jaminan apabila debitor wanprestasi diatur dalam Pasal 1178 KUHPerdata. Pasal 1178 KUHPerdata ini menegaskan bahwa segala janji yang memberikan hak kepada si berpiutang (kreditor) untuk memiliki benda yang dijadikan objek jaminan adalah batal demi hukum. Artinya bahwa dalam akta hipotek dilarang memuat janji yang menyebutkan ketika debitor wanprestasi, maka kreditor dengan sendirinya menjadi pemilik benda yang dijadikan jaminan hipotek. Hal ini tentu saja bertentangan dengan fungsi dari jaminan, yaitu jaminan berfungsi sebagai sarana perlindungan dan kepastian akan pelunasan utang oleh debitor, bukan sebagai pemindahan hak milik atas objek jaminan.

Selain dalam KUHPerdata, pengaturan mengenai larangan ini juga terdapat dalam peraturan lain diluar KUHPerdata, yaitu terhadap lembaga jaminan Hak Tanggungan larangan memiliki objek jaminan ini diatur dalam Pasal 12 UU Hak Tanggungan. Pasal 12 UU Hak Tanggungan menyebutkan bahwa setiap janji yang memberikan kewenangan kepada pemegang hak tanggungan untuk memiliki objek hak tanggungan apabila debitor wanprestasi adalah batal demi hukum. Hal ini berkaitan dengan fungsi dari hak tanggungan sebagai jaminan yang dibebankan pada hak atas tanah untuk pelunasan utang tertentu. Dalam hak tanggungan terdapat hak untuk melunasi utang dari hasil penjualan benda jaminan dan tidak memberi hak bagi kreditor untuk memiliki benda jaminan.

Adanya larangan janji untuk memiliki objek jaminan apabila debitor wanprestasi ini merupakan bentuk perlindungan hukum bagi debitor atau pemberi hak tanggungan karena nilai objek hak tanggungan lazimnya lebih tinggi daripada nilai utang yang diberikan. Sehingga alasan dari diaturnya larangan ini dalam hak tanggungan adalah untuk melindungi kepentingan debitor atau pemilik jaminan atas objek hak tanggungan yang umumnya bernilai lebih tinggi daripada nilai utangnya dan merupakan cerminan fungsi jaminan sebagai sarana kepastian akan pelunasan utang.

Hak tanggungan pada dasarnya merupakan upaya debitor untuk meyakinkan kreditor akan pelunasan piutangnya. Apabila debitor cidera janji, pemegang hak tanggungan pertama mempunyai hak untuk menjual objek hak tanggungan atas kekuasaan sendiri melalui pelelangan umum serta mengambil pelunasan piutangnya dari hasil penjualan tersebut. (Pasal 6 UUHT). Pasal 12 Undang-Undang No. 4 tahun 1996 tentang Hak Tanggungan (UUHT) pada intinya mengatakan, Kreditor tidak boleh membuat janji yang menyatakan apabila debitor cidera janji maka otomatis kreditor akan memiliki objek jaminan. Jika perjanjian semacam ini dibuat, maka perjanjian tersebut 
batal demi hukum. Hak Tanggungan adalah salah satu bentuk jaminan kebendaan disamping gadai, fidusia, dan hipotek. Perlu diingat, prinsip ataupun tujuan dalam hukum jaminan bukan untuk memindahkan hak miliki atas suatu barang melainkan untuk menjamin pelunasan utang. (Gatot Supramono, 2013, : 59).

Peraturan Bank Indonesia Nomor 13/26/PBI/2011 telah menentukan bahwa upaya penyelesaian AYDA paling lama 1 (satu) tahun sejak pengambilalihan agunan, bukan berarti bahwa setiap proses penyelesaian tersebut akan berjalan dengan lancar, misalkan terjadi hambatan-hambatan seperti yang telah dijelaskan sebelumnya. Pada dasarnya UU Hak Tanggungan memberikan kemudahan bagi kreditor dalam mempercepat proses pelaksanaan agunan yang diambil alih sehingga tidak melebihi jangka waktu yang telah ditetapkan dalam menyelesaikan pelunasan piutangnya apabila debitor cidera janji.

Pengambil alihan agunan melalui eksekusi atas objek Hak Tanggungan dalam praktiknya sering dilawan atas dasar ketidakjelasan status hukum kepemilikan objek jaminan, atau jumlah utang yang belum pasti (fix). Dalam beberapa kasus ditemukan bahwa penyelesaian kredit macet melalui eksekusi objek jaminan Hak Tanggungan berdasarkan titel eksekutorial mengalami hambatan dan membutuhkan waktu yang panjang. Pada Putusan Nomor 383/Pdt.G/2008/PN.Jkt.Bar. ditemukan bahwa diperlukan waktu sekitar 4 DOI: https://doi.org/10.29313/aktualita.v0i0.5903 (empat) tahun (1 Oktober 2007 sampai dengan 10 November 2011) bagi kreditor untuk mengeksekusi jaminan Hak Tanggungan. Kenyataan ini tentu belum sejalan dengan tujuan dari UU Hak Tanggungan yang salah satunya menyatakan bahwa eksekusi Hak Tanggungan dilaksanakan secara mudah dan pasti. Hal ini tentu saja akan menimbulkan ketidakpastian hukum terhadap objek Hak Tanggungan yang dikuasai oleh bank karena melebihi jangka waktu yang telah ditetapkan. Pada akhirnya akan melanggar legalitas aspek Hukum Jaminan, yaitu bahwa jaminan atau agunan tidak boleh dimiliki oleh kreditor. Aspek hukum ini sesuai dengan ketentuan Pasal 12 UU Hak Tanggungan yang menyebutkan bahwa kreditor dilarang secara serta merta menjadi pemilik objek Hak Tanggungan karena debitor cidera janji.

Berdasarkan Penjelasan Pasal 12 UU Hak Tanggungan, ketentuan ini dimaksudkan untuk melindungi kepentingan debitor dan pemberi Hak Tanggungan lainnya, terutama jika nilai objek Hak Tanggungan melebihi besarnya utang yang dijamin. Objek Hak Tanggungan yang diperjanjikan untuk dimiliki oleh Pemegang Hak Tanggungan maka batal demi hukum. Untuk melindungi aspek hukum diatas, maka Pasal 12A UU Perbankan menentukan bahwa bank dapat membeli agunan melalui pelelangan maupun diuar pelelangan berdasarkan penyerahan sukarela maupun berdasarkan kuasa untuk menjual diluar 
pelelangan apabila debitor tidak memenuhi kewajibannya, dengan ketentuan agunan yang telah dibeli tersebut wajib dicairkan secepatnya. (Pasal 12 A ayat (1) UU Perbankan). Penjelasan pasal ini menyebutkan bahwa pembelian agunan oleh bank dimaksudkan untuk mempercepat penyelesaian kewajiban debitor. Bank tidak diperbolehkan untuk memiliki agunan yang telah dibelinya tersebut dan secepatcepatnya harus dijual kembali agar hasil penjualan agunan dapat segera dimanfaatkan oleh bank untuk menyelesaikan kewajiban debitor.

Penguasaan agunan oleh bank pada saat pelaksanaan AYDA yang melebihi jangka waktu 1 (satu) tahun tetap tidak dapat dimiliki oleh bank itu, meskipun masih dikuasai guna penyelesaian kewajiban debitor. Pasal 12A UU Perbankan merupakan salah satu wujud kepastian hukum bagi objek Hak Tanggungan yang dikuasai oleh bank pada saat pelaksanaan AYDA lebih dari 1 (satu) tahun. Kepastian hukum dalam peraturan ini untuk mempertahankan prinsip bahwa jaminan bukan untuk memiliki barangnya, tetapi menjamin bahwa debitor akan melakukan kewajibannya hingga lunas atau apabila macet dapat secepatnya dijual untuk melunasi utang debitor tersebut. Prinsip hukum jaminan di atas, sama dengan prinsip yang terkandung dalam Pasal 12 UUHT yaitu Hak Tanggungan berisi hak untuk melunasi utang dari hasil penjualan benda jaminan dan bukan memberikan hak bagi kreditor untuk memiliki benda jaminan. Dengan kata lain, tujuan dari hak tanggunan ini untuk menjamin pelunasan utang jika debitor cidera janji dengan mengambil uang hasil penjualan objek jaminan itu. (YLBHI, 2007 : 149).

Pelaksanaan AYDA melalui pelelangan umum tidak terlepas dari kesulitan dalam mencari pembeli objek Hak Tanggugan yang akan dieksekusi melalui lelang tersebut. Kesulitan ini menyebabkan waktu yang diperlukan untuk menjual objek Hak Tanggungan semakin banyak. Namun, dalam Pasal 78 Peraturan Menteri Keuangan Nomor 27/PMK.06/2016 tentang Petunjuk Pelaksanaan Lelang menentukan bahwa pembelian agunan oleh bank dilakukan oleh pihak lain yang ditunjuk kemudian dalam jangka waktu 1 (satu) tahun terhitung mulai tanggal pelaksanaan lelang. Apabila dalam jangka waktu 1 (satu) tahun telah terlampaui belum menemukan pembeli objek Hak Tannggungan yang akan dilelang, maka bank ditetapkan sebagai pembeli. Peraturan ini memberikan kepastian hukum bahwa terhadap tidak adanya pembeli objek Hak Tanggungan yang akan dilelang dalam pelaksanaan AYDA menetapkan bank sebagai pembeli. Pelaksanaan AYDA oleh bank bertujuan untuk mempercepat penyelesaian kewajiban debitor yang macet. Salah satunya melalui eksekusi agunan yang sebelumnya telah dijaminkan kepada kreditor untuk memperoleh fasilitas kredit. Kreditor biasanya melakukan eksekusi melalui parate eksekusi. 
Parate eksekusi adalah melakukan ekseskusi sendiri tanpa bantuan atau campur tangan pengadilan atau hakim. Dalam pelaksanaan parate eksekusi terhadap objek jaminan, kreditor tidak secara serta merta melaksanakan parate eksekusi, akan tetapi terlebih dahulu dilakukan teguran-teguran sesuai dengan kebiasaan hukum yang berlaku dalam praktek lembaga perbankan. Apabila debitor tidak melaksanakan kewajibannya barulah dilakukan langkah parate eksekusi terhadap objek jaminannya.

Dapat diperhatikan ketentuan yang terdapat dalam Pasal 6 UU Hak Tanggungan, yang menentukan bahwa apabila debitor cidera janji, pemegang Hak Tanggungan pertama mempunyai hak untuk menjual objek Hak Tanggungan atas kekuasaan sendiri melalui pelelangan umum, serta mengambil pelunasan piutangnya dari hasil penjualan tersebut. Dalam penjelasan Pasal 6 UU Hak Tanggungan disebutkan bahwa hak untuk menjual objek Hak Tanggungan atas kekuasaan sendiri merupakan salah satu perwujudan dari kedudukan yang diutamakan yang dipunyai oleh pemegang Hak Tanggungan atau pemegang Hak Tanggungan pertama dalam hal terdapat lebih dari satu pemegang Hak Tanggungan. Hak tersebut didasarkan pada janji yang diberikan oleh pemberi Hak Tanggungan bahwa apabila debitor cidera janji, pemegang Hak Tanggungan berhak untuk menjual objek Hak Tanggungan melalui pelelangan umum tanpa memerlukan DOI: https://doi.org/10.29313/aktualita.v0i0.5903 persetujuan lagi dari pemberi Hak Tanggungan dan selanjutnya mengambil pelunasan piutangnya dari hasil penjualan itu lebih dabhulu daripada kreditor-kreditor yang lain.

Sisa hasil penjualan tetap menjadi hak pemberi Hak Tanggungan. Dengan demikian dapat dikatakan bahwa hak untuk menjual objek Hak Tanggungan atas kekuasaan sendiri merupakan salah satu perwujudan dari kedudukan diutamakan yang dimiliki oleh pemegang Hak Tanggungan, atau oleh pemegang Hak Tanggungan pertama dalam hal terdapat lebih dari satu pemegang Hak Tanggungan. Karena Pasal 6 UU Hak Tanggungan memberikan hak kepada pemegang Hak Tanggungan untuk dapat melakukan parate eksekusi, dengan kata lain diperjanjikan atau tidak diperjanjikan, hak itu demi hukum dipunyai pemegang Hak Tanggungan. Oleh karena itu Sertifikat Hak Tanggungan yang merupakan tanda bukti adanya Hak Tanggungan yang diberikan oleh Kantor Pertanahan dan yang memuat irah-irah "DEMI KEADILAN BERDASARKAN KETUHANAN YANG MAHA ESA", mempunyai kekuatan eksekutorial yang sama dengan putusan pengadilan yang telah memperoleh kekuatan hukum tetap. Parate eksekusi Hak Tanggungan dapat dilakukan langung tanpa fiat ekseksusi Pengadilan berdasarkan Surat Edaran Badan Urusan Piutang dan Lelang Negara (BUPLN) Nomor SE-21/PN/1998 jo. SE-23/PN/2000 tentang 
Petunjuk Pelaksanaan Pasal 6 Undang-Undang Nomor 4 Tahun 1996 tentang Hak Tanggungan telah sesuai dengan ketentuan Pasal 6 UU Hak Tanggungan yang menentukan bahwa kreditor dapat melakukan eksekusi Hak Tanggungan dengan kewenangan sendiri. Pelaksanaan parate eksekusi merupakan suatu perlindungan bagi pihak kreditor agar dalam proses pemberian kredit, khususnya setelah kredit tersebut direalisasi dan telah diterima debitor, pihak kreditor tidak dirugikan oleh pihak debitor yang melakukan wanprestasi terutama dalam melaksanakan perjanjian kredit, juga untuk memberikan kepastian hukum pengembalian kredit yang telah diberikan kreditor kepada debitor dan kepastian hukum merupakan salah satu asas essensial dalam negara hukum. Dapat dikatakan bahwa kreditor yang mendapaktan kepastian hukum dalam pengambilalihan agunan melalui parate eksekusi dapat mempercepat prosesnya sehingga pelaksanaan AYDA tidak melebihi jangka waktu yang telah ditetapkan, yaitu paling lama 1 (satu) tahun. Dalam pelaksanaan parate eksekusi Hak Tanggungan terdapat kendalakendala meliputi kendala yuridis dan kendala sosiologis. Kendala yuridis utamanya adalah Putusan Mahkamah Agung Nomor 3021/K/Pdt/1984 (30 Januari 1984) yang menyatakan bahwa parate eksekusiyang dilakukan tidak dengan meminta persetujuan pengadilan negeri, meskipun didasarkan Pasal 1178 ayat (2) KUHPerdata, adalah perbuatan melawan hukum dan lelang DOI: https://doi.org/10.29313/aktualita.v0i0.5903 yang dilakukan adalah batal demi hukum. Hal ini berpotensi menimbulkan ketidakpastian hukum. Sementara kendala sosiologisnya adalah perlawanan melalui gugatan pengadilan, yang dilakukan oleh debitor ketika mengetahui bahwa bank akan melakukan upaya eksekusi atas tanah dan atau bangunan yang menjadi jaminan kredit dan kesulitan bank mencari pembeli lelang atas tanah dan bangunan yang menjadi objek lelang eksekusi tersebut. Oleh karena itu sering terjadi perlawanan daari pihak debitor yang menyebabkan proses pelaksanaan agunan yang diambil alih melalui eksekusi objek Hak Tanggungan melebihi jangka waktu yang telah ditetapkan yaitu paling lama 1 (satu) tahun.

Selain parate eksekusi, jenis eksekusi lain dapat dilakukan oleh bank selaku kreditor. Ketentuan tentang jenis eksekusi objek Hak Tanggungan secara menyeluruh diatur dalam Pasal 20 UU Hak Tanggungan, yaitu Eksekusi dengan Penetapan Pengadilan (fiat eksekusi) dan Eksekusi dengan penjualan di bawah tangan. Eksekusi dengan Penetapan Pengadilan (fiat eksekusi) terdapat dalam Pasal 14 ayat (2) jo Pasal 20 ayat (2) UU Hak Tanggungan. Bank dapat mengajukan permohonan penetapan pengadilan (fiat eksekusi) melalui pengadilan negeri maupun pengadilan agama (untuk bank syariah atau lembaga syariah) merujuk pada ketentuan Pasal 14 Peraturan Menteri Keuangan Republik Indonesia Nomor 27/PMK.06/2016 tentang Petunjuk Pelaksanaan Lelang. 
Praktik pelakanaan eksekusi yang umumnya dikabulkan melalui penetapan pengadilan adalah eksekusi jaminan akibat adanya perjanjian kredit antara nasabah dengan pihak bank. Hal ini disebabkan karena pada umumnya utang dan penjaminan dalam perjanjian kredit dapat dibuktikan dengan cepat dan sederhana. Dalam pengajuan permohonan eksekusi atas Sertifikat Hak Tanggungan yang berirah-irah "DEMI

KEADILAN BERDASARKAN KETUHANAN YANG MAHA ESA" kepada Ketua Pengadilan Negeri agar dikabulkan maka permohonan tersebut sebaiknya berisikan tuntutan sebagai berikut: 1) Melakukan peneguran kepada termohon (debitor) agar memenuhi isi Sertifikat Hak Tanggungan; 2) Apabila dalam waktu 8 (delapan) hari sejak peneguran, termohon (debitor) melalaikannya maka Ketua Pengadilan Negeri akan melakukan Sita Eksekusi terhadap benda jaminan milik termohon (debitor); 3) Agar Ketua Pengadilan Negeri menetapkan Lelang Eksekusi terhadap benda jaminan tersebut untuk pelunasan utang termohon (debitor). Eksekusi dengan penjualan di bawah tangan terdapat dalam Pasal 20 ayat (2) dan ayat (3) UU Hak Tanggungan. Yang dimaksud penjualan di bawah tangan (Offsetting) adalah penjualan atas tanah yang dijadikan jaminan dan dibebani Hak Tanggungan oleh kreditor sendiri secara langsung kepada orang lain/pihak yang berminat, tetapi juga dibantu oleh pemilik tanah dan bangunan yang dimaksud.
Penjualan dibawah tangan dapat dilakukan asalkan hal tersebut disepakati oleh pemberi dan pemegang Hak Tanggungan, dan dengan memenuhi syarat bahwa pelaksanaan penjualan dibawah tangan ini hanya dapat dilakukan setelah lewat waktu 1 (satu) bulan sejak diberitahukan secara tertulis oleh pemberi dan/atau pemegang Hak Tanggungan kepada pihak-pihak yang berkepentingan dan diumumkan sedikit-dikitnya 2 (dua) surat kabar yang beredar di daerah yang bersangkutan dan/atau media massa setempat, serta tidak ada pihak yang menyatakan keberatan. Pelaksanaan eksekusi ini dimaksudkan untuk mempercepat penjualan objek Hak Tanggungan dan dengan harga penjualan tinggi.

Pasal 31 KMK Nomor 557/KMK.01/1999 tentang petunjuk pelaksanaan Lelang menyatakan bahwa : 1) Dalam hal pembeli bertindak untuk orang lain atau badan harus disertai dengan surat kuasa; 2) Bank sebagai kreditor dapat membeli agunannya melalui lelang, dengan menyatakan bahwa pembelian tersebut dilakukan untuk pihak lai yang akan ditunjuk kemudian; 3)Pembelian agunan sebagaimana dimaksud pada ayat (2) harus disertai dengan akta notaris. Dalam ilmu hukum, akta notaris yang memuat keterangan untuk siapa seseorang melakukan pembelian dikenal dengan Akta De Command. Penjualan kembali agunan yang telah diambilalih oleh bank terkadang menemui kendala, khususnya agunan yang berupa benda tidak bergerak. 
Sehingga Pengambilalihan agunan/asset debitor /penjamin oleh bank, apabila dalam waktu 1 (satu) tahun belum terjual juga maka harus dilakukan balik nama kepada bank yang bersangkutan, yang akan berdampak pada neraca keuangan bank.

Tujuan penyelesaian kredit macet melalui pengambilalihan aset debitor (AYDA) tersebut adalah untuk mengurangi kredit bermasalah, karena dengan diambil alihnya aset tersebut, maka hutang debitor secara langsung dianggap lunas, karena menumpuknya kredit bermasalah akan berpengaruh terhadap tingkat kesehatan bank. Hal tersebut diperbolehkan dan diatur oleh UU Perbankan dengan syarat pengambilalihan dilakukan untuk mencairkan aset tersebut kembali dalam jangka waktu paling lama 1 (satu) tahun untuk bank umum. Dalam pengambilalihan agunan diperlukan alas hak yang berupa akta jual beli agunan antara kreditor sebagai pembeli dan debitor sebagai penjual. Akta Jual Beli (AJB) merupakan alas hak atau alas hukum untuk memindahkan hak milik debitor berupa agunan kepada kreditor. Bagi agunan barang tidak bergerak berupa tanah dan bangunan yang melekat diatasnya maka akta jual beli dibuat oleh Pejabat Pembuat Akta Tanah (PPAT).

Pada Paragraf ketiga Penjelasan Pasal 12A UU Perbankan mengatakan bahwa bank tidak diperbolehkan memiliki agunan yang dibelinya dan secepat-cepatnya harus dijual kembali agar hasil penjualan agunan dapat DOI: https://doi.org/10.29313/aktualita.v0i0.5903 segera dimanfaatkan oleh bank. Oleh karena itu, secara praktik aset-aset yang dimiliki oleh bank memiliki status sebagai aset non-operasional. Walaupun pada Pasal 28 PMK 27/2016 sebagaimana diulas di atas mengatakan bahwa bank dianggap sebagai pembeli dari barang agunan apabila tidak mendapatkan pembeli atas agunan tersebut, namun tidak terdapat ketegasan mengenai bank pemerintah atau swasta yang dapat memiliki agunan tersebut.

Dalam praktik di lapangan bank swasta diduga melakukan pemilikan atas tanah melalui mekanisme AYDA. Hal ini dapat bertentangan dengan Peraturan Pemerintah Nomor 38 Tahun 1963 Tentang Penunjukan Badan-Badan Hukum yang Dapat Mempunyai Hak Milik atas Tanah (PP 38/1963). Lebih lanjut, Pasal 110 Peraturan Menteri Agraria Nomor 3 Tahun 1997 tentang Pendaftaran Tanah (Permenag 3/1997) memiliki semangat yang seragam dengan UU Perbankan dan PP 38/1963 yang mengatur bahwa bank pemerintah (disini lebih tegas karena tidak menyebut bank swasta) dapat mendaftarkan secara langsung nama pembeli akhir yang ditunjuk bank tersebut. Lalu, pada Pasal 110 ayat (3) Permenag 3/1997 juga mengatur bahwa proses balik nama karena bank sudah dianggap pembeli harus dilakukan dengan proses penandatanganan akta jual-beli antara bank yang ditetapkan sebagai pembeli dengan pembeli dikemudian hari. Hal ini menunjukan bahwa dalam hal ini Pemenag 3/1997 juga memiliki semangat yang sama 
untuk melakukan pencairan terhadap agunan yang diambil alih.

Terkait dengan pemilikan agunan oleh bank masih terdapat permasalahan berdasarkan Pasal 12 Undang-Undang No.4 Tahun 1996 Hak Tanggungan Atas Tanah Beserta BendaBenda yang Berkaitan dengan Tanah yang pada pokoknya mengatur bahwa janji yang memberikan kewenangan kepada pemegang hak tanggungan untuk memiliki objek hak tanggungan apabila debitor cidera janji. Tidak ada pengaturan jelas mengenai mekanisme pembagian kelebihan hasil penjualan barang agunan yang telah dilakukan oleh bank. Dalam hal ini Peraturan Pemerintah harus dengan jelas memberikan pengaturan mengenai fungsi pengawasan dari pengembalian hasil penjualan agunan apabila hasil tersebut melebihi total piutang dari bank.

Tidak adanya pengawasan ini berbahaya bagi keadaan bisnis di Indonesia karena dalam hal bank mengincar margin keuntungan dari penjualan barang agunan di luar kegiatan perbankan maka seharusnya hal tersebut tidak dimungkinkan karena hal tersebut bukan kegiatan perbankan sebagaimana diamanatkan oleh UU Perbankan. Pengaturan ini berfungsi untuk menyelamatkan bank dari persoalanpersoalan penggelapan hasil penjualan agunan dari debitor yang dirugikan. Untuk mencegah permasalahan hukum di kemudian hari, dalam praktiknya proses AYDA selalu diikuti dengan balik nama sebagai bentuk pengalihan kepemilikan di hadapan Notaris/PPAT. Hal ini guna melindungi kepentingan hukum si penerima AYDA dari tuntutan/gugatan di kemudian hari.

\section{PENUTUP}

\section{Kesimpulan}

Berdasarkan hasil penelitian dan pembahasan yang telah diuraikan sebelumnya, maka dapat diambil kesimpulan sebagai berikut:

1. Salah satu upaya penyelamatan kredit macet pada bank adalah dengan dilakukannya pengambilalihan asset debitor (AYDA). Pemilihan penyelesaian kredit melalui AYDA dilakukan berdasarkan penyelesaian yang dianggap terbaik bagi bank, dalam arti memperkecil resiko kerugian bank dan/atau mengoptimalkan manfaat dan/atau keuntungan (mempercepat penyelesaian kredit bermasalah/memperoleh recovery yang optimal). Proses pelaksanaan penyelesaian kredit macet melalui pengambilalihan asset debitor / Asset settlement (AYDA).

2. Tujuan penyelesaian kredit macet melalui pengambilalihan aset debitor (AYDA) tersebut adalah untuk mengurangi kredit bermasalah, karena dengan diambil alihnya aset tersebut, maka hutang debitor secara langsung dianggap lunas, karena menumpuknya kredit bermasalah akan berpengaruh terhadap tingkat kesehatan bank. Terkait dengan pemilikan agunan oleh 
bank masih terdapat permasalahan berdasarkan Pasal 12 Undang-Undang No.4 Tahun 1996 Hak Tanggungan Atas Tanah Beserta Benda-Benda yang Berkaitan dengan Tanah yang pada pokoknya mengatur bahwa janji yang memberikan kewenangan kepada pemegang hak tanggungan untuk memiliki objek hak tanggungan apabila debitor cidera janji. Sertipikat Hak Milik harus dialihkan ke atas nama perorangan dan tidak boleh di ke atas nama Perseroan Terbatas.Tidak ada pengaturan jelas mengenai mekanisme pembagian kelebihan hasil penjualan barang agunan yang telah dilakukan oleh bank. Dalam hal ini Peraturan Pemerintah harus dengan jelas memberikan pengaturan mengenai fungsi pengawasan dari pengembalian hasil penjualan agunan apabila hasil tersebut melebihi total piutang dari bank.

\section{Saran}

Berdasarkan kesimpulan yang telah dikemukakan di atas, maka peneliti mengajukan saran sebagai berikut:

1. Sebaiknya sebagai salah satu upaya penyelamatan kredit macet pada bank adalah dengan dilakukannya pengambilalihan asset debitor (AYDA), akan tetapi dilakukan dengan memperhatikan ketentuan yang ada sehingga tidak menjadi persoalan dikemudian hari dikarenakan terdapat suatu ketentuan atau prinsip yang dilanggar yang akan merugikan pihak kreditor sendiri.

2. Sebaiknya pembelian agunan oleh bank berdasarkan Akta De Command harus dialihkan ke pihak lain yang ditunjuk dalam jangka waktu 1 (satu) tahun terhitung mulai tanggal pelaksanaan lelang. Tidak adanya pengawasan ini berbahaya bagi keadaan bisnis di Indonesia karena dalam hal bank mengincar margin keuntungan dari penjualan barang agunan di luar kegiatan perbankan maka seharusnya hal tersebut tidak dimungkinkan karena hal tersebut bukan kegiatan perbankan sebagaimana diamanatkan oleh UU Perbankan.

\section{DAFTAR PUSTAKA}

\section{a) Buku-Buku}

Gatot Supramono, Perjanjian utang piutang, Kencana Prenada Media Group, Jakarta, 2013.

Hariri, Wawan Muhwan, 2011, Hukum Perikatan, Pustaka Setia, Bandung. Indrawati, Soewarso, Aspek Hukum Jaminan Kredit, Jakarta, Institut Bankir Indonesia, 2002.

J.Satrio, Parate Eksekusi Sebagai Sarana Mengatasi Kredit Macet, Bandung, Citra Aditya Bhakti, 1993.

Kasmir, Bank dan Lembaga Keuangan Lainnya, Jakarta, PT. Raja Grafindo, 2000.

Muhammad Abdulkadir, Murniati Rilda, Lembaga Keuangan dan 
Pembiayaan, Bandung, PT. Citra

Aditya Bakti, 2000.

Muljadi, Kartini dan Gunawan Widjaja, Seri Hukum Harta Kekayaan: Hak Istimewa,Gadai, dan Hipotek, Kencana, Jakarta, 2007.

Poesoko, Herowati, Parate Executie Obyek Hak Tanggungan, Laksbang Pressindo, Yogyakarta, 2008.

Rachmadi Usman, Hukum Jaminan Keperdataan, Sinar Grafika, Jakarta, 2008.

Subekti, Aneka Perjanjian, PT. Citra Aditya Bakti, Bandung, 1995.

Hukum Perjanjian, Intermasa, Jakarta, 2002.

Sudikno Mertokusumo, Penemuan Hukum, penerbit Universitas Atma Jaya Yogyakarta, Yogyakarta, 2010. Suharno, Analisa Kredit, Jakarta, Djambatan, 2003.

YLBHI, Panduan Bantuan Hukum di Indonesia,YLBHI dan PSHK, Jakarta, 2007.

\section{b) Peraturan Perundang-undangan}

Undang - Undang Nomor 5 Tahun 1960 Tentang Peraturan Dasar Pokok Pokok Agraria Lembaran Negara Republik Indonesia Tahun 1960 Nomor 104.

Undang - Undang Nomor 4 Tahun 1996 Tentang Hak Tanggungan
Lembaran Negara Republik Indonesia Tahun 1996 Nomor 42. Undang - Undang Nomor 10 Tahun 1998 tentang perubahan atas UndangUndang No.7 Tahun 1992 tentang Perbankan Lembaran Negara Republik Indonesia Tahun 1998 Nomor 182.

Peraturan Bank Indonesia Nomor 6/25/PBI/2004 tentang Rencana Bisnis Bank Umum.

Peraturan Bank Indonesia Nomor 14/15/PBI/2012 tentang Penilaian Kualitas Aset Bank Umum.

\section{c) Sumber Lain}

Bachtiar, Sibarani, Kredit Macet dan Upaya Penanggulangannya (Himpunan dari sebagian Karya Tulis yang pernah diterbitkan Surat Kabar dan majalah), bandung, 2001. Jurnal Mimbar Vol XXVIII No.2, “Asas dan Jenis Akad Dalam Hukum Ekonimi Syariah: Implementasinya pada Usaha Bank Syariah" oleh Neni Sri Imaniyati - Fakultas Hukum UNISBA, Bandung, Desember 2011, diakses melalui https://media.neliti.com/media/publi cations/7419-ID-asas-dan-jenisakad-dalam-hukum-ekonomisyariah-implementasinya-padausaha-bank.pdf , Diakses pada 
tanggal 22 Februari 2020, Pukul 21.55 WIB.

Jurnal "Hukum Perbankan - untuk lingkungan sendiri" oleh Neni Sri Imaniyati, $\mathrm{SH}, \quad \mathrm{MH} .$, , Fakultas Hukum UNISBA, Bandung, 2008, diunduh melalui https://www.academia.edu/8946981 /hukum_perbankan, Diakses pada tanggal 22 Februari 2020, Pukul 22.45 WIB.

file:///D:/HUKUM\%2OPERBANKAN/144 85-51207-1-SM.pdf, Diakses pada tanggal 24 Februari 2020, pukul 23.07WIB.

https://www.djkn.kemenkeu.go.id/artikel/ baca/12717/Lelang-Hak-TagihMengapa-TIdak.html, Diakses tanggal 22 Februari 2020, pukul 13.30 .

https://www.djkn.kemenkeu.go.id/kpknljakarta5/baca-berita/17833/AYDABerpotensi-Tingkatkan-

Produktifitas-Lelang.html (diakses pada tanggal 23 Februari 2020 pukul 12.53 WIB)

http://www.hukumonline.com/klinik/detail /t4dbe6ff9al6fd/bagaimana-bankmelakukan-ayda,Diakses pada tanggal 23Februari 2020, pukul 21.44 WIB.

http://lontar.ui.ac.id/file?file $=$ digital/203 34349-T32614-Nalia\%20Safitri.pdf diakses pada tanggal 24 Februari 2020 pukul 00.59 WIB) 